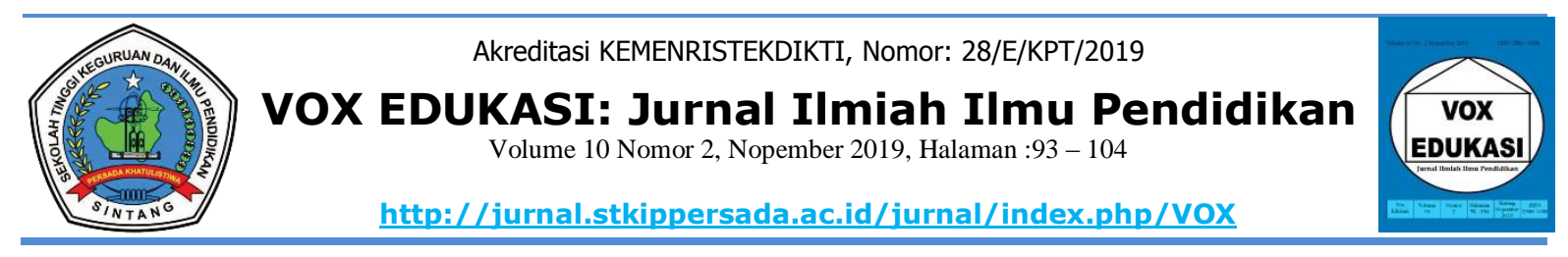

\title{
PENINGKATAN KETERAMPILAN INTELEKTUAL MELALUI PENERAPAN MODEL PROJECT CITIZEN PADA MATA KULIAH PENDIDIKAN KEWARGANEGARAAN
}

\author{
Rohani $^{1}$, \& Muhammad Anwar Rube'i ${ }^{2}$ \\ ${ }^{1}$ Program Studi PPKn Fakultas Ilmu Pendidikan dan Pengetahuan Sosial IKIP PGRI Pontianak \\ ${ }^{2}$ Program Studi PPKn Fakultas Ilmu Pendidikan dan Pengetahuan Sosial IKIP PGRI Pontianak \\ Email:1,2 rohani@ikippgriptk.ac.id,anwarptk87@gmail.com
}

\begin{tabular}{|c|c|}
\hline INFO AR & TIKEL \\
\hline Riwayat $A$ & tikel: \\
\hline Menerima & : 4 Oktober 2019 \\
\hline Revisi & : 19 Nopember 2019 \\
\hline Diterima & : 29 Nopember 2019 \\
\hline
\end{tabular}

Kata Kunci:

keterampilan intektual, project citizen.

Keywords:
intellectual skills, project citizen

Korespondensi:

Rohani

Program Studi PPKn Fakultas Ilmu Pendidikan dan

Pengetahuan Sosial IKIP PGRI Pontianak

Jl. Ampera Nomor 88 Pontianak78116, Telepon (0561) 748219 Fax. (0561) 6589855,

Email: rohani@ikippgriptk.ac.id

\section{ABSTRAK}

Penelitian ini didasari oleh masih rendahnya keterampilan mahasiswa dalam berpikir kritis terhadap kebijak publik dan isu-isu kebangsaan yang sedang marak saat ini. Penggunaan model project citizen diharapkan dapat membantu meningkatkan keterampilan intelektual mahasiswa terhadap masalah kebangsaan dan kebijakan publik. Penelitian ini bertujuan untuk meningkatkan keterampilan intelektual melalui penerapan model project citizen pada mata kuliah Pendidikan Kewarganegaraan. Metode yang digunakan yaitu penelitian tindakan dengan bentuk Penelitian Tindakan Kelas (PTK) yang meliputi tiga siklus. Tiap siklus terdiri dari empat tahapan yaitu perencanaan, pelaksanaan, pengamatan, dan refleksi. Adapun data penelitian ini diambil melalui tes dan nontes. Berdasarkan analisis data, dapat disimpulkan bahwa Penerapan model project citizen dapat meningkatkan keterampilan intektual hal ini dapat dilihat dari hasil analisis data keterampilan intektual pada siklus I mencapai 68\%, siklus II mencapai $74 \%$ dan siklus III mencapai $85 \%$.

\section{ABSTRACT}

This research is based on the lack of student skills in critical thinking about public policy and national issues that are rife today. The use of the project citizen model is expected to help improve students' intellectual skills on nationality and public policy issues. This study aims to improve intellectual skills through the application of the project citizen model in the Civics Education course. This research is a Classroom Action Research (CAR) which includes three cycles. Each cycle consists of four stages: planning, acting, observing, and reflecting. The method used is descriptive method with a form of qualitative research and the design is classroom action research. The data of this study were taken through tests and non-tests. Based on data analysis, it can be concluded that the application of the project citizen model can improve intellectual skills. This can be seen from the results of the analysis of intellectual skills data in the first cycle reaching $68 \%$, the second cycle reaching $74 \%$ and the third cycle reaching $85 \%$.

(c)2019 LPPM STKIP Persada Khatulistiwa Sintang

\section{PENDAHULUAN}

Pendidikan yang diberikan di

Perguruan Tinggi diharapkan dapat

mengembangkan potensi mahasiswa untuk menghadapi tantangan keterampilan abad ke21.

Salah satu tantangan pendidikan dewasa ini adalah membangun keterampilan abad 21,diantaranya adalah keterampilan melek teknologi informasi dan komunikasi (information \& communication technology literacy skill), keterampilan berpikir kritis (critical thinking skill), keterampilan memecahkan masalah (problem solving skill), keterampilan berkomunikasi efektif (effective 
communication skill) dan keterampilan berkolaborasi (collaborate skill). Keterampilan tersebut itulah yang menurut Perserikatan Bangsa Bangsa (PBB) merupakan ciri dari masyarakat era global saat ini, yaitu masyarakat berpengetahuan (knowledge-based soceity) (Chaeruman, 2010). Pendapat lain juga dikemukakan Suarsana dan Mahayukti (2013: 264) yang menyatakan bahwa tantangan pendidikan abad ke 21 yaitu melek teknologi informasi dan komunikasi (information \& communication technology literacy skill), keterampilan berpikir kritis (critical thingking skill), keterampilan berkomunikasi efektif (effective communication skill) dan keterampilan berkolaborasi (collaborate skill). Hal ini dapat dimaknai bahwa pendidikan yang diberikan di Perguruan Tinggi mampu mencetak lulusan yang cerdas, melek teknolgi, mampu memecahkan masalah, berpikir kritis, mampu berkomuikasi dengan baik serta mampu berkolaborasi dengan orang lain. Untuk mencapai hal ini diperlukan sebuah model dalam pembelajan yang dapat mengembangkan keterampilan abad 21 ini.

Senada dengan pendapat di atas Branson (1999) mengemukakan ada beberapa potensi kewarganegaraan yang perlu dikembangkan dalam dalam menghadapi era globalisasi yaitu pengetahuan kewarganegaraan(civicknowledge),

keterampilan kewarganegaraan (civicskill) dan watak atau karakter kewarganegaran (civic diposition) sehingga dapat menumbuhkan karakter warga negara yang baik. Berdasarkan beberapa pendapat diatas dapat dimaknai bahwa dalam menghadapi era globalisasi hendaknya mengembangkan kompetensi kewarganegaraan (civiccompetence). Salah satu kompetensi kewarganegaraan yang ingin diteliti oleh peneliti yaitu keterampilan kewarganegaraan (civic skill). Keterampilan kewarganegaraan yang dimiliki oleh mahasiswa misalnya dapat dilihat dari kemampuannya mengkritisi kebijakan publik. Mahasiswa sebagai intelektual mudah seharusnya dapat memiliki kekritisan terhadap setiap kebijakan publik yang dikeluarkan oleh pemerintah baik skala nasional maupun lokal. Murdiono (2010). Dari beberapa kutipan tersebut dapat dimaknai bahwa keterampilan kewarganegaraan (civic skills) sangat penting untuk ditingkatkan dalam proses pembelajaran Kenyataannya berdasarkan observasi yang dilakukan oleh peneliti dan hasil wawancara dengan dosen pengampu mata kuliah diperoleh kurangnya partisipasi aktif mahasiswa dalam proses pembelajaran, masih banyak mahasiswa yang malu dalam bertanya, kurangnya kekritisan mahasiswa terhadap kebijakan publik yang dikeluarkan oleh pemerintah. Hal ini dapat dilihat dari ketika dosen menyampaikan permasalahan tekait dengan kebijakan publik, mahasiswa kurang antusias untuk menanggapi kasus tersebut. Disisi lain mahasiswa juga bersifat apatis. Model pembelajaran yang dipandang cocok oleh peneliti untuk meningkatkan civicskill yaitu model projectcitizen.

Untuk memperkuat bahwa penerapan model dapat meningkatkan civic skills maka peneliti mengutip pendapat dari Murdiono (2010) hasil penelitiannya menyimpulkan bahwa meningkatnya keterampilan 
kewarganegaraan mahasiswa melalui penerapan strategi pembelajaran berbasis masalah. Pendapat lain juga dikemukakan Mulyoto dan Samsuri (2017) hasil penelitiannya menunjukkan bahwa terdapat pengaruh yang signifikan penerapan model project citizen dengan pendekatan saintifik dalam pembelajaran PPKn terdapat penguasaan kompetensi kewarganegaraan dibandingkan dengan menggunakan model pembelajaran berbasis masalah dengan pendekatan saintifik. Selanjutnya Komalasari (2012) menyatakan hasil penelitiannya First, contextual learning in Civic Education has significant effect on civic skills of Junior High School students in West Java, Indonesia. Second, contextual learning develops students'thinking and participative skills through cooperative learning, selfregulated learning, service learning, problem based learning,inquiry-based learning, project-based learning,and value learning strategies.Third, contextual learning has significant effect on civic skills because it is natural for students and develops meaningful democratic learning to develop the students'critical thinking and participative skills in their daily lives. Hal ini dapat dimaknai bahwa pembelajaran kontekstual memberikan pengaruh yang signifikan dalam pembelajaran Pendidikan Kewarganegaraan.

Berdasarkan uraian yang telah dikemukakan, maka masalah penelitian dalam penelitian ini adalah (1) belum tersedianya perangkat pembelajaran berbasis project citizen, (2) kurangnya partisipasi aktif mahasiswa dalam proses pembelajaran, masih banyak mahasiswa yang malu dalam bertanya, kurangnya kekritisan mahasiswa terhadap kebijakan publik yang dikeluarkan oleh pemerintah. Adapun pertanyaan penelitiannya (1) bagaimana perencanaan model pembelajaran project citizen untuk meningkatkan keterampilan intelektual?. (2) Bagaimana gambaran pelaksanaan model project citizen untuk meningkatkan keterampilan intelektual?. (3) Bagaimana peningkatan keterampilan intelektual dengan penerapan model project citizen?.

\section{METODE PENELITIAN}

Metode yang digunakan dalam penelitian ini adalah penelitian tindakan kelas. Penelitian tindakankan adalah penelitian yang dilakukan untuk meningkatkan isu-isu sosial. Gregory (2013) menegaskan bahwa: "Action research is a process of systematic inquiry that seeks to improve social issues affecting the lives of everyday people". Hal ini dapat dipahami bahwa penelitian tindakan adalah suatu proses penyelidikan sistematis yang bertujuan untuk meningkatkan isu-isu sosial mempengaruhi kehidupan manusia sehari-hari. Sejalan dengan pendapat Burns (2010) mengemukakan bahwa: "Action research is research carried out in the classroom by the teacher of the course, mainly with the purpose of solvinga problem or improving the teaching/learning process". Hal ini menegaskan bahwa penelitian tindakan adalah penelitian yang dilakukan di kelas oleh guru kursus, terutama dengan tujuan memecahkan masalah atau meningkatkan proses pengajaran atau pembelajaran. Berdasarkan 
pendapat diatas dapat disimpulkan bahwa penelitian tindakan adalah kolaborasi antara peneliti dengan kelompok sasaran dengan tujuan untuk memecahkan masalah dalam kegiatan pembelajaran. Langkah yang dilakukan peneliti dalam peaksanaan penelitian adalah tahapan perencanaan, pelakanaan, pengamatan dan refleksi.

Setting penelitian dilaksanakan di Kampus IKIP PGRI Ponianak, berlokasi di Jalan Ampera Nomor 88, Kecamatan Pontianak Kota, Provinsi Kalimantan Barat. Subyek penelitian adalah mahasiswa semester II yang menempuh matakuliah Pendidikan Kewarganegaraan tahun akademik 2018/2019, dengan jumlah 40 mahasiswa. teknik pengumpulan data dalam penelitian adalah teknik pengukuran, observasi, wawancara, dokumentasi, dan studi literatur. Alat pengumpul data yang digunakan adalah angket, lembar observasi dan studi dokumenter. Pengumpulan data dilakukan melalui angket, observasi, dan dokumentasi. Teknik analisis data yang dilakukan yaitu rata-rata (mean) dan analisis data kualitatif. Teknik analisis data yang digunakan adalah teknik statistik deskriptif komperatif serta teknik analisis kualitatif. Teknik deskriptif komparatif digunakan untuk data kuantitatif, yakni dengan membandingkan hasil antar siklus. Teknik analisis data kualitatif yaitu menggambarkan proses terjadinya pembelajaran serta peningkatan yang terjadi.

\section{HASIL DAN PEMBAHASAN}

Penelitian ini dilaksanakan dalam tiga (III) siklus. Setiap siklus terdiri dari perencanaan, pelaksanaan, pengamatan (observasi) dan refleksi. Jumlah mahasiswa yang mengikuti pembelajaran di kelas sebanyak 40 mahasiswa. Berikut deskripsi data hasil penelitian tentang peningkatan keterampilan intelektual melalui penerapan model project citizen pada mata kuliah Pendidikan Kewarganegaraan.

\section{Perencanaan Model Pembelajaran Project} Citizen

Pada pertemuan pertama dosen menyampaikan langkah-langkah penerapan model project citizen dan memberikan arahan hal-hal apa saja yang ditekankan dalam proses pembelajaran mata kuliah Pendidikan Kewarganegaraan. Pada siklus I, kegiatan Perencanaan model pembelajaran project citizen yang dilakukan peneliti seperti membuat peta kajian materi, Rencana Pembelajaran Semester (RPS), Rencana Pelaksanaan Pembelajaran, instrumen penelitian, angket dan dokumentasi, media pembelajaran lembar observasi kegiatan dosen dan mahasiswa serta mempersiapkan pembagian hadiah kelompok, Selanjutnya, pada siklus II, Kegiatan perencanaan tindakan pada siklus II didasarkan pada hasil refleksi siklus I. Adapun kegiatan perencanaan pada siklus II hampir sama dengan siklus I, namun pada tahap ini peneliti lebih memperbaiki penjelasan langkah-langkah model pembelajaran project citizen pada Rencana Pembelajaran Semester (RPS). Pada siklus III, kegiatan perencaaan tindakan yang dibuat sama dengan siklus II. Perencanaan-perencanaan tersebut telah disepakati oleh dosen mitra. Selanjutnya, dosen 
kolaborasi akan menginformasikan kepada mahasiswa mengenai langkah-langkah pembelajaran yang akan dilakukan, agar mahasiswa dapat belajar sesuai dengan rencana yang telah dipersiapkan sebelumnya. Berdasarkan uraian tersebut di atas, maka dapat disimpulkan bahwa kegiatan perencanaan tindakan dalam penerapan model project citizen sudah baik.

\section{Pelaksanaan Model Pembelajaran Project} Citizen

Berdasarkan hasil penelitian dan observasi yang dilakukan peneliti diperoleh bahwa penerapan model pembelajaran project citizen sudah berjalan dengan baik. Hal ini dapat dilihat dari langkah-langkah yang diterapkan oleh dosen kolaborasi seperti, mengidentifikasi masalah, memilih masalah yang ingin dibahas di kelas, mahasiswa mengumpulkan informasi, mengembangkan portofolio, dan menyajikan portofolio. Secara prosedural project citizen menerapkan langkah-langkah seperti 1) mengidentifikasi masalah. pada tahap ini dosen memberikan temauntuk didiskusikan sesuai dengan Standar Kompetensi yang telah ditentukan sebelumnya. Setelah itu dosen memberikan contoh masalah-masalah kewarganegaraan berkembang dimasyarakat. 2) Memilih masalah sebagai bahan kajian kelas. Pada tahap memilih masalah, setiap anggota kelompok berunding terlebih dahulu dengan teman-teman sekelompoknya. Setelah itu menentukan masalahapa yang akan dibahas. 3) Mengumpulkan informasi. Setelah setiap kelompok menentukan masalah atau tema, maka mahasiswa dengan deskripsi tugas kelompoknya harus menentukan tempat-temapat atau sumber- sumber manayang bisa mendapatkan informasi tambahan. Informasi ini dapat ditemukan melalui wawancara dengan pihak terkait, informasi dari surat kabar, majalah, dan media elektronik lainnya. 4) mengembangkan portofolio kelas . Pada tahap ini setiap kelompok mulai mengembangkan portofolio kelompok. Masingmasing bagian kelompok khusus bertanggung jawab untuk mengembangkan satu bagian dari portofolio kelompok inti. Setiap kelompok dapat menyusun portofolio kelas, baik portofolio bagian tayangan maupun portofolio bagian dokumentasi yang diperoleh dari hasil penelitian. 5). Menyajikan portofolio. Setiap kelompok menyajikan hasil pekerjaannya dihadapan para hadirin. Presentasi itu dikenal dengan sebutan showcase dilakukan dihadapan tiga atau sampai empat orang juri yang didatangkan dari luar sekolah/kampus.6). Merefleksikan pengalaman belajar. Refleksi pengalaman belajar ini dilakukan oleh dosen PPKn sebagai koreksi dari apa yang telah dipelajari dan menggali nilai-nilai yang didapatan dari proses pembelajaran sebelumnya.

\section{Tabel 1}

Penerapan Model Project Citizen dalam Mata Kuliah Pendidikan Kewarganegaraan Siklus I, Siklus II, dan Siklus III 


\begin{tabular}{clccc}
\hline $\mathbf{N}$ & \multicolumn{3}{c}{ Siklus } \\
\cline { 2 - 5 } $\mathbf{0}$ & Aspek & Siklu & Siklu & Siklu \\
& s II & s III \\
1 & $\begin{array}{l}\text { Mengidentifikasi } \\
\text { Masalah }\end{array}$ & $69 \%$ & $86 \%$ & $87 \%$ \\
2 & $\begin{array}{l}\text { Memilih } \\
\text { Masalah } \\
\text { sebagai bahan }\end{array}$ & $71 \%$ & $79 \%$ & $86 \%$ \\
kajian kelas \\
3 & $\begin{array}{l}\text { Mengumpulkan } \\
\text { informasi } \\
4\end{array}$ & $71 \%$ & $80 \%$ & $85 \%$ \\
\hline $\begin{array}{l}\text { Mengembangk } \\
\text { an portofolio }\end{array}$ & $69 \%$ & $74 \%$ & $84 \%$ \\
\hline 5 & $\begin{array}{l}\text { Menyajikan } \\
\text { portofolio } \\
\text { Merefleksikan } \\
\text { pengalaman } \\
\text { belajar }\end{array}$ & $72 \%$ & $79 \%$ & $84 \%$ \\
\hline $\begin{array}{l}\text { Rata-rata } \\
\text { Persentase }\end{array}$ & $\mathbf{6 8 \%}$ & $\mathbf{7 6 \%}$ & $\mathbf{8 6 \%}$ \\
\hline
\end{tabular}

Berdasarkan tabel di atas, maka dapat disimpulkan bahwa terdapat peningkatan pelaksanaan model project citizen dari siklus I, ke siklus II dan terjadi peningkatan pada siklus III. Pada siklus I memperoleh persentase $68 \%$, terjadi peningkatan pada siklus II memperoleh persentase $76 \%$, pada siklus III terdapat peningkatan yang siginifikan dengan mencapai persentase $86 \%$. Dengan demikian dapat disimpulkan bahwa penerapan model project citizen pada mata kuliah Pendidikan Kewarganegaraan sudah berjalan dengan baik.

\section{Peningkatan Keterampilan Intelektual menggunakan Model Project Citizen}

Berdasarkan data hasil penelitian tindakan baik pada siklus I, siklus II dan siklus III dapat disimpulkan bahwa penerapan model project citizen pada mata kuliah Pendidikan Kewarganegaraan sudah berjalan dengan baik. Hal ini dapat dilihat dari adanya peningkatan untuk aspek-aspek model project citizen tiap siklusnya. Hal ini dapat dilihat dari hasil analisis pengolahan data yang dilakukan oleh peneliti pada tabel 2 di bawah ini.

Tabel 2

\section{Peningkatan Keterampilan Intelektual \\ Dalam Penerapan Model Project Citizen Siklus I, siklus II, dan siklus III}

\begin{tabular}{ccccc}
\hline $\mathbf{N}$ & Aspek & Sikl & Sikl & Sikl \\
$\mathbf{0}$ & & us I & us II & $\begin{array}{c}\text { us } \\
\text { III }\end{array}$ \\
\hline 1 & $\begin{array}{l}\text { Mengidentifik } \\
\text { asi masalah }\end{array}$ & $67 \%$ & $74 \%$ & $86 \%$ \\
2 & $\begin{array}{l}\text { Mendeskripsi } \\
\text { kan masalah }\end{array}$ & $70 \%$ & $74 \%$ & $85 \%$ \\
3 & $\begin{array}{l}\text { Mengambil } \\
\text { sikap }\end{array}$ & $67 \%$ & $75 \%$ & $84 \%$ \\
& $\begin{array}{l}\text { Rata-rata } \\
\text { persentase }\end{array}$ & $\mathbf{6 8 \%}$ & $\mathbf{7 4 \%}$ & $\mathbf{8 5 \%}$ \\
\hline
\end{tabular}

Berdasarkan tabel analisis data di atas, diperoleh simpulan bahwa keterampilan intelektual mengalami peningkatan tiap siklusnya dimana siklus $168 \%$, siklus II $74 \%$ dan siklus III mencapai $85 \%$. Terjadinya peningkatan tersebut dikarenakan guru telah menguasai dan melaksanakan model project citizen sesuai dengan langkah-langkah yang sesuai dengan skenario pembelajaran yang telah dibuat. Selain itu, mahasiswa sudah memahami dengan baik materi yang disampaikan oleh guru dan sudah memahami dengan baik langkahlangkah model project citizen. Pada siklus I, Mahasiswa masih kaku dengan model ini, sehingga masih kurang mampu dalam mengidentifikasi masalah, mendeskripsikan masalah dan pengambilan sikap. pada siklus II mahasiswa sudah mulai memahami sintak 
pembelajaran model ini, sehingga mahasiswa sudah ada sebagian mengidentifikasi masalah, sudah mulai mampu menjelaskan masalah dan mampu mengambil sikap dalam proses diskusi dan tanyajawab. pada siklus III mahasiswa sudah terbiasa dengan langkah-langkah model project citizen, sehingga sudah mampu dalam mengidentifikasi masalah, mendeskripsikan masalah dan sangat respek dalam pengambilan sikap baik dalam memimpin kelompoknya, membuat laporan dan reaktif dalam diskusi dan tanyajawab.

Dari uraian di atas maka dapat disimpulkan bahwa penerapan model project citizen dapat meningkatkan keterampilan intelektual mahasiswa..

\section{Pembahasan}

Berdasarkan hasil penelitian tersebut diatas, dapat disimpulkan bahwa penerapan project citizen telah mampu meningkatkan keterampilan intelektual mahasiswa Prodi PPKn IKIP PGRI pontianak. Hal ini terlihat selama siklus I, II menunjukan peningkatan yang memuaskan terutama terjadi peningkatan pada siklus III, pada siklus ini mahasiswa sudah mampu mengidentifikasi masalah, sudah mampu menjelaskan masalah dan mampu mengambil sikap dalam memimpin kelompok, menyelesaikan tugas dengan baik dan tepat waktu, aktif dalam proses diskusi dan tanyajawab. Hasil penelitian ini sejalan dengan penelitian yang dilakukan oleh Rohani, (2016) hasil penelitiannya menyimpulkan bahwa meningkatnya keterampilan kewarganegaraan mahasiswa melalui penerapan strategi pembelajaran berbasis masalah. Pendapat lain juga dikemukakan Murdiono (2010) hasil penelitiannya menunjukkan bahwa terdapat pengaruh yang signifikan penerapan model project citizen dengan pendekatan saintifik dalam pembelajaran PPKn terdapat penguasaan kompetensi kewarganegaraan dibandingkan dengan menggunakan model pembelajaran berbasis masalah dengan pendekatan saintifik. Selanjutnya hasil penelitian luqman (2017), bahwa penerapan model pembelajaran project citizen dapat meningkatkan keterampilan berpikir kritis dan kreatif, yang dilakukan melalui enam langkah, yaitu: mengidentifikasi masalah; memilih masalah; mengumpulkan informasi; mengembangkan portofolio; menyajikan portofolio; dan refleksi pada pengalaman belajar.

\section{Peningkatan}

keterampilan intetelektual ini disebabkan oleh faktor perencaaan yang dibuat oleh peneliti dan dosen mitra kolaborasi dalam penerapan model ini. Perencanan ini perlu mereka rancang agar tujuan yang diinginkan dapat terwujud dengan baik dan efektif sehingga tidak ditemukan kendala yang cukup berarti dalam konteks pengajaran. Perencanaan dalam ini berarti sebagai proses penyususnan materi ajar, penggunaan media, penggunaan pendekatan dan metoda pengajaran, serta penilian dalam suatu alokasi waktu untuk mencapai kompetensi tertentu yang telah dirumuskan (Novalita, 2014). tujuan utama dari perencanaan pembelajaran adalah untuk menunjukkan perencanaan, pengembangan, penilaian dan pengelolaan proses pembelajaran (Isman, 2011: 136). Hal ini menunjukkan betapa 
pentingnya perencanaan pembelajaran bagi setiap proses pembelajaran. sebelum dilaksankannya pelaksanaan tindakan, perlu adanya perencanaan pembelajaran hal ini sebagaimana diungkapkan Arikunto (2014) bahwa dalam tahapan penyusunan rencana, peneliti menemukan titik-titik atau fokus peristiwa yang mendapatkan perhatian khusus untuk diamati kemudian membuat sebuah instrumen pengamatan untuk membuat peneliti merekam fakta yang terjadi selama tindakan berlangsung. Hal ini dapat dimaknai bahwa sebelum menerapkan suatu model pembelajaran maka perlu dibuat perencanaan baik terlebih dahulu agar proses pembelajaran berjalan dengan lancar. Selain itu peneliti perlu menyiapkan materi pembelajaran, media dan instrumen penelitian.

Untuk melaksanakan model pembelajaran project citizen yang akan diterapkan di kampus harus mempertimbangkan waktu. Pembelajaran Pendidikan Kewarganegraan dengan menggunakan model project citizen, karena untuk mengukur keberhasilan tidak terfokus pada nilai, tetapi pada perubahan tingkah laku dari siswa itu sendiri. Dalam pelaksanaan model pembelajaran Pendidikan Kewarganegaraan berbasis berbasis project citizen yang dipraktekkan pada mahasiswa Prodi PPKn, tidak terlepas dari prinsip dasar pembelajaran seperti yang dikemukan oleh Budimansyah (2002 : 8 -13) yaitu :

1. Prinsip Belajar Siswa Aktif adalah proses pembelajaran yang berpusat pada siswa. Aktivitas siswa hampir di seluruh proses pembelajaran, mulai dari fase perencanaan, fase kegiatan lapangan, sampai pada fase pelaporan.

2. Kelompok Belajar Kooperatif, yaitu proses pembelajaran yang berbasis kerjasama, baik kerjasama antar siswa, komponen-komponen sekolah, instansi atau lembaga terkait yang diperlukan pada saat para siswa merencanakan kunjungan terhadap lembaga tertentu atau meninjau suatu kawasan yang menjadi tanggung jawab lembaga tertentu.

3. Pembelajaran partisipatorik dimana siswa belajar sambil melakoni (learning by doing). Salah satu bentuk pelakonan itu adalah siswa belajar hidup berdemokrasi, karena dalam model ini siswa belajar untuk menghargai dan menerima pendapat orang lain.

4. Reaktive Teaching, dimana guru harus menciptakan strategi yang tepat agar siswa mempunyai motivasi belajar yang tinggi, sehingga materi pelajaran selalu menarik dan tidak membosankan.

Pendapat lain Budimansyah (2008) menegaskan bahwa landasan pemikiran Project Citizen terletak pada satu kerangka yang terdiri atas lima bagian tentang gagasan pendidikan dan politik. Pertama, diperlukannya keterlibatan warga negara dalam kehidupan berwarga negara. Kedua, Inti dari Pendidikan Kewarganegaraan kaya akan nilai jika para mahasiswa ikut ambil bagian secara aktif dalam kehidupan berwarga negara. Ketiga, dengan menggali masalahmasalah yang ada di komunitas mereka sendiri, maka mereka akan mengetahui prinsip-prinsip demokrasi yang merupakan inti dari pengetahuan kewarganegaraan. Keempat, Project Citizen dimaksudkan untuk diterapkan terutama oleh para siswa sekolah menengah atau usia-usia remaja pradini (berusia sekitar 10-15 tahun) yang mulai bergeser dari berpikir kongkrit menuju berpikir abstrak. Kelima, Project Citizen menganggap siswa sebagai sumber kewarganegaraan yang gagasan dan 
tenaganya dapat secara nyata dicurahkan pada

masalah-masalah kebijakan publik

Adapun langkah-langkah yang harus ditempuh dalam proses pelaksanaan model pembelajaran project citizen pada mata kuliah

Pendidikan Kewarganegaraan sebagai berikut :

1. Mengidentifikasi masalah kebijakan publik di masyarakat atau masalah yang berkaitan dengan materi pelajaran. Dengan tujuan untuk berbagi pengetahuan di antra siswa dengan teman-teman dan orang lain tentang masalah kebijakan publik atau materi pelajaran. Hal ini hendaknya dapat membantu siswa memperoleh informasi yang cukup untuk mengidentifikasi secara cermat masalah-masalah yang akan dipelajari.

2. Memilih masalah tentang kebijakan publik untuk kajian kelas. Tahap ini bertujuan agar kelas memilih satu masalah tentang kebijakan publik atau yang berkaitan dengan materi pelajaran yang akan menjadi kajian kelas setelah memiliki cukup informasi.

3. Mengumpulkan informasi tentang kebijakan publik atau materi pelajaran yang akan dikaji oleh kelas. Tujuan pada tahap ini mengumpulkan informasi dari sumbersumber informasi yang telah diidentifikasi sebelumnya. Hal ini hendaknya membantu kelas menemukan jawaban-jawaban untuk memecahkan masalah yang berkenaan dengan kebijakan publik atau materi pelajaran.

4. Membuat portofolio kelas, tahap ini bertujuan membuat portofolio setelah para siswa melakukan penelitian lapangan. Kelas hendaknya dibagi ke dalam 4 kelompok. Setiap kelompok akan bertangggungjawab untuk membuat satu bagian portofolio. Bahan-bahan dalam portofolio hendaknya memuat dokumentasi terbaik yang telah dikumpulkan oleh kelas dan kelompok dalam meneliti masalah. Bahan-bahan dalam portofolio itupun hendaknya memuat bahan-bahan tulis tangan asli dan atau karya seni asli para siswa.

5. Penyajian portofolio, tujuan pada tahap ini adalah 1) untuk menginformasikan kepada hadirin tentang pentingnya masalah yang diidentifikasikan di masyarakat, 2) untuk menjelaskan dan mengevaluasi kebijakan alternatif sehingga hadirin dapat memahami keuntungan dan kerugian dari setiap kebijakan, 3) untuk mendiskusikan kebijakan yang dipilih kelas sebagai kebijakan terbaik untuk mengatasi masalah, 4) untuk membuktikan bagaimana kelas dapat menumbuhkan dukungan dalam masyarakat dan lembaga-lembaga perwakilan rakyat dan pihak eksekutif yang terkait dengan masalah yang dikaji.

6. Merefleksi pengalaman belajar, tujuan pada tahap ini adalah untuk merefleksi (bercermin) pada pengalaman belajar yang telah mereka alami dan lakukan baik secara mandiri maupun secara bersama-sama dengan temannya. Kegiatan ini merupakan satu cara untuk belajar, menghindari kesalahan di masa yang akan datang dan meningkatkan kinerja. Pada akhirnya refleksi adalah proses perenungan, pengendapan, dan penghargaan. (Winataputra, $2001:$ 4, Budimansyah, 2001 : $9-19)$

Berdasarkan hasil penelitian terhadap pelaksanaan model project citizen pada mata kuliah Pendidikan Kewarganegaraan, bahwa terdapat peningkatan pelaksanaan model project citizen dari siklus I, ke siklus II dan terjadi peningkatan pada siklus III. Pada siklus I memperoleh persentase $68 \%$, terjadi peningkatan pada siklus II memperoleh persentase $76 \%$, pada siklus III terdapat peningkatan yang siginifikan dengan mencapai persentase $86 \%$. Dengan demikian dapat disimpulkan bahwa penerapan model project citizen pada mata kuliah Pendidikan Kewarganegaraan sudah berjalan dengan baik.

Penerapan model project citizen pada mata kuliah Pendidikan Kewarganegaraan di IKIP PGRI Pontianak sebagai berikut: 1) mengidentifikasi masalah. pada tahap ini dosen memberikan temauntuk didiskusikan sesuai dengan Standar Kompetensi yang telah 
ditentukan sebelumnya. Setelah itu dosen memberikan contoh masalah-masalah kewarganegaraan berkembang dimasyarakat. 2) Memilih masalah sebagai bahan kajian kelas. Menurut Budimansyah (2009) menjelaskan tujuan dari kegiatan ini adalah kelas dapat memilih satu masalah sebagai bahan kajian kelas. Dengan demikian kelas memiliki satu masalah yang merupakan pilihan bersama untuk dijadikan bahan kajian kelas. Kegiatan pemilihan masalah diawali dengan membangkitkan minat siswa untuk mengkaji dan menyelesaikan masalah. Pada tahap memilih masalah, setiap anggota kelompok berunding terlebih dahulu dengan teman-teman sekelompoknya. Setelah itu menentukan masalahapa yang akan dibahas. 3) Mengumpulkan informasi. Setelah setiap kelompok menentukan masalah atau tema, maka mahasiswa dengan deskripsi tugas kelompoknya harus menentukan tempat-temapat atau sumbersumber mana yang bisa mendapatkan informasi tambahan. Informasi ini dapat ditemukan melalui wawancara dengan pihak terkait, informasi dari surat kabar, majalah, dan media elektronik lainnya. Kegiatan mengumpulkan informasi memberikan banyak pengalaman belajar kepada siswa (Budimansyah, 2010). Melalui aktivitas ini siswa membiasakan untuk mengambil keputusan dengan dukungan data dan informasi yang akurat.

Langkah selanjutnya adalah; 4) mengembangkan portofolio kelas. Mengembangkan portofolio merupakan langkah selanjutnya setelah siswa menyelesaikan proses mengumpulkan informasi selengkap mungkin terkait masalah yang dikaji. Kelas dibagi menjadi empat kelompok. Masing- masing kelompok akan bertanggung jawab untuk mengembangkan satu bagian portofolio (Budimansyah, 2009). Selanjutnya Budimansyah menjelaskan bahwa bahan-bahan yang dimasukkan dalam portofolio hendaknya dokumen- dokumen yang telah dikumpulkan pada langkah sebelumnya, yaitu mengumpulkan informasi. Pada tahap ini setiap kelompok mulai mengembangkan portofolio kelompok. Masingmasing bagian kelompok khusus bertanggung jawab untuk mengembangkan satu bagian dari portofolio kelompok inti. Setiap kelompok dapat menyusun portofolio kelas, baik portofolio bagian tayangan maupun portofolio bagian dokumentasi yang diperoleh dari hasil penelitian.

Langkah selanjutnya adalah; 5). Menyajikan portofolio. Presentasi portofolio atau yang disebut showcase dapat dilakukan dihadapan 2 s.d. 4 dewan juri. Melalui kegiatan ini, siswa dibekali dengan pengalaman belajar tentang cara mempresentasikan ide-ide dan pemikiran kepada orang lain (Budimansyah, 2009). Setiap kelompok menyajikan hasil pekerjaannya dihadapan para hadirin. Presentasi itu dikenal dengan sebutan showcase dilakukan dihadapan tiga atau sampai empat orang juri yang didatangkan dari luar sekolah/kampus.6). Merefleksikan pengalaman belajar. Kegiatan ini merupakan salah satu cara untuk belajar, untuk menghindari agar jangan sampai melakukan kesalahan yang sama, dan untuk meningkatkan kemampuan yang sudah dimiliki siswa (Budimansyah, 2009). Pada langkah ini, lebih lanjut Budimansyah (2009) menjelaskan bahwa hendaknya refleksi pengalaman belajar 
menggambarkan secara singkat tentang: apa yang telah dipelajari siswa/kelas dan bagaimana caranya; dan cara apa yang akan siswa gunakan jika mereka nantinya akan mengembangkan portofolio yang lain (Budimansyah, 2010). Refleksi pengalaman belajar ini dilakukan oleh dosen PPKn sebagai koreksi dari apa yang telah dipelajari dan menggali nilai-nilai yang didapatan dari proses pembelajaran sebelumnya.

\section{SIMPULAN}

Berdasarkan analisis data dan hasil yang dilakukan dengan dua siklus dapat disimpulkan bahwa model pembelajaran project citizen dapat meningkatkan keterampilan intelektual mahasiswa program studi Pendidikan Pancasila dan Kewarganegaraan IKIP PGRI Pontianak. Pada siklus 1 memperoleh persentase sebesar 69\% dengan kategori cukup baik, selanjutnya pada siklus II terjadi peningkatan dengan memperoleh persentase sebesar $74 \%$ dan pada siklus III terdapat peningkatan yang sangat signigifikan dengan memperoleh persentase sebesar $85 \%$. Hal ini menunjukkan bahwa penerapan model project citizen yang dilakukan oleh dosen mitra sudah baik dan telah sesuai dengan langkah-langkah pembelajaran yang sudah dirancang dalam skenario pembelajaran model project citizen.

Kegiatan Perencanaan model pembelajaran project citizen yang dilakukan peneliti dan dosen kolaborasi seperti membuat peta kajian materi, Rencana Pembelajaran Semester (RPS), Rencana Pelaksanaan Pembelajaran, instrumen penelitian, angket dan dokumentasi, media pembelajaran lembar observasi kegiatan dosen dan mahasiswa serta mempersiapkan pembagian hadiah kelompok.

Peningkatan pelaksanaan model project citizen dari siklus I, ke siklus II dan terjadi peningkatan pada siklus III. Pada siklus I memperoleh persentase $68 \%$, terjadi peningkatan pada siklus II memperoleh persentase $76 \%$, pada siklus III terdapat peningkatan yang siginifikan dengan mencapai persentase $86 \%$. Dengan demikian dapat disimpulkan bahwa penerapan model project citizen pada mata kuliah Pendidikan Kewarganegaraan sudah berjalan dengan baik.

\section{UCAPAN TERIMA KASIH}

Penelitian ini dibiayai oleh Kementerian Riset, Teknologi, dan Pendidikan Tinggi melalui program Penelitian Dosen Pemula dengan Kontrak Nomor 009/L.202.103/PDP/IV/2019, sehingga peneliti mengucapkan terima kasih yang sebesarnya kemenristekdikti atas bantuan yang diberikan.

\section{DAFTAR RUJUKAN}

Arikunto, S.(2014). Penelitian Tindakan Kelas. Jakarta: Bumi Aksara.

Branson, M.S. dkk. (1999). Belajar "Civic Education" dari Amerika. Yogyakarta: LKIS dengan didukung The Asia Foundation (TAF)

Budimansyah, D. (2009). Inovasi pembelajaran Project Citizen. Program Studi Pendidikan Kewaraganegaraan UPI.

Budimansyah,D. Dan Karim Suryadi (2008). PKn dan Masyarakat Multikultural. Bandung: ProgramStudi PKn SPs UPI.

Budimansyah,D. (2008). Revitalisasi Pembelajaran Pendidikan Kewarganegaraan melalui Praktik Belajar 
Kewarganegaraan (Project Citizen)'. Acta Civicus Vol. 1. Nomor 2, April 2008.

Burns, A. (2010). Doing Action Research In English Language Teaching A Guide For Practitioners. Australia:Departemen Of Linguistich, Macquarie University.

Chaeruman, Uwes. (2010).E-Learning dalam Pendidikan Jarak Jauh. Jakarta:Kemendiknas.

Gregory,S.C.H. (2013). “The Importance Of action Research In teacher Education Program”. Journal Issues In Educational Research. (online) tersedia. www.iier.org.au. (31 Maret2016).

Mahayukti G.A dan Suarsana. I M, (2013). Pengembangan E-Modul Berorientasi Pemecahan Masalah Untuk Meningkatkan Keterampilan Berpikir Kritis Mahasiswa. Jurnal Pendidikan Indonesia, hal. 264

Isman, A. (2011). Instructional Design in Education: New Model. Turkish. Online Journal of Educational Technology - TOJET, 10(1), 136-142.

Komalasari,K. (2012).The Effect of Contextual Learning in Civic Education on Students Civic Skills. EDUCARE:International Journal for Education Studies. Volume 4 Number 2.

Luqman. (2017). Penerapan Model Project Citizen Untuk Meningkatkan Keterampilan Berpikir Kritis dan Kreatif Siswa. Jurnal Ilmu Pendidikan, Volume 2 Nomor 1, Juni 2017:

44-59. http://journal2.um.ac.id/index.php/jktpk/ar ticle/download/2203/1297

Mulyoto. G.Pdan Samsuri. (2017). Pengaruh Model Project Citizen dengan Pendekatan Saintifik Terhadap Penguasaan Kompetensi Kewarganegaraan dalam Pembelajaran Pendidikan Pancasila dan Kewarganegaraan. Jurnal Civicus Volume14 No. 1.

Murdiono. (2010). Peningkatan Keterampilan Kewarganegaraan CivicSkills) Melalui
Penerapan Strategi Pembelajaran Berbasis Masalah (Problem Based Learning). Jurnal Penelitian Ilmu Pendidikan. Volume3 No.1.

Novalita, R. (2014). Pengaruh Perencanaan Pembelajaran Terhadap Pelaksanaan Pembelajaran. Jurnal Lentera, vol. 14, No. 2 Maret 2014. http://jurnal.umuslim.ac.id/index.php/LTR1/art icle/download/201/124

Rohani, (2016). Meningkatkan Kemampuan Berpikir Kritis Mahasiswa Melalui Metode Diskusi Bervariasi, Ucej: Untirta Civic Education JournalVolume1 No. 2 hal. 112222

Slavin, R. E. (2008). Educational Psycology: Theory and Practice. Terjemahan oleh Marianto Samosir. Jakarta: PT Indeks.

Sumanto. (2011). Modul Pengembangan Media Pembelajaran SD. Malang: Panitia Sertifikasi Guru (PSG) Rayon 15, Universitas Negeri Malang, Kementerian Pendidikan Nasional 